\title{
Anti-dermatophyte activity of Pelargonium graveolens essential oils against dermatophytes
}

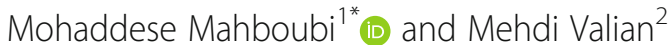

\begin{abstract}
Background: Pelargonium graveolens as valuable aromatic plant is used for extracting the essential oil, which their biological effects such as antioxidant, antimicrobial, anti-inflammatory and wound healing effects have been confirmed.

Methods: In this study, the anti-dermatophyte effects of nine $P$. graveolens essential oils were confirmed against Microsporum canis, M. gypseum, Trichophyton rubrum, T. mentagrophytes, and T. schoenleinii by mycelium growth inhibition percent and micro-broth dilution assays. The chemical composition of essential oils was determined by GC and GC-MS.

Results: The main components of $P$. graveolens essential oils and their percentages changed from one sample to others. The highest growth inhibition percent and the lowest MIC values of $P$. graveolens essential oils for dermatophytes were for $E_{20}$ with $95 \%$ geraniol content, followed by $E_{4}$ and $E_{14}$ with highest amounts of geraniol (21\%) and citronellol (30-35\%) contents.

Conclusion: Therefore, the use of $P$. graveolens essential oils with high geraniol and citronellol is recommended for dermatophytes. Animal models studies of dermatophytes are required to confirm the efficacy and application of $P$. graveolens essential oils in human studies.
\end{abstract}

Keywords: P. graveolens, Essential oil, Geraniol, Citronellol, Dermatophytes

\section{Introduction}

Pelargonium genus as perennial small shrubs compromises more than 250 species [1], P. graveolens (Pelargonium roseum) is highly valued by industries for producing geranium essential oil [2]. According to BS ISO 4371-2012, P. graveolens essential oil from different geographical origins should have geraniol (5-20\%), citronellol (18-43\%), citronellyl formate (4-12\%), geranyl formate $(1-8 \%)$, and linalool $(2-11 \%)$ as the main components [3]. The chemical profile of $P$. graveolens essential oil is affected from its geographical origin. The pharmacological effects of $P$. graveolens essential oil such as antioxidant [4, 5], antimicrobial [6-9], antiinflammatory $[10,11]$ and wound healings [12] activities

\footnotetext{
* Correspondence: mahboubi1357@yahoo.com

${ }^{1}$ Department of Microbiology, Medicinal Plant, Research Center of Barij, Kashan, Iran

Full list of author information is available at the end of the article
}

is well documented. Furthermore, evaluation the antifungal activities of $P$. graveolens essential oil have been the subject of different experimental studies [13-16]. The antifungal activities of $P$. graveolens essential oil were confirmed against Trichophyton spp. [15], and Candida albicans $[13,14,16]$. Although, there are one report on anti-dermatophyte effects of $P$. graveolens essential oil against Trichophyton spp. [15], but there is no investigation to compare the anti-dermatophyte effects of $P$. graveolens essential oils against different kinds of dermatophytes (Microsporum canis, M. gypseum, Trichophyton rubrum, T. mentagrophytes, and T. schoenleinii).

Dermatophytes (Trichophyton, Microsperum, Epidermophyton) are one of major cause of superficial fungal infections with an estimate lifetime risk of $20-25 \%$ [17]. The use of topical and systemic drugs (Azoles/allylamines, terbinafine) is used for treatment of dermatophytes that are associated with adverse effects and 
appearance of resistant microbial strains [18]. Different kinds of essential oils have been evaluated against dermatophytes. Prunus armeniaca, Prunus dulcis var. amara, Olea europaea, Mentha piperita [19], Artemisia sieberi [20], Juniperus communis ssp. alpina, J. oxycedrus ssp. oxycedrus and $J$. turbinate [21] were effective against dermatophytes.

Therefore, the subject of this study was to evaluate the anti-dermatophyte effects of nine different $P$. graveolens essential oils from Iran, Germany and India against dermatophytes.

\section{Materials and methods}

\section{$P$. graveolens essential oils}

Nine different $P$. graveolens essential oils with identified chemical profiles as Table 1 were used in this study. Essential oils were prepared by Barijessence Pharmaceutical Company (Kashan, Iran). The chemical compositions of essential oil were determined by Quality Control of BarijEssence Pharmaceutical Company, Kashan, Iran.

\section{Dermatophytes strains}

Microsporum canis PTCC (Persian Type Culture Collection) 5069, Microsporum gypseum PTCC 5070, Trichophyton rubrum PTCC 5143, Trichophyton mentagrophytes PTCC 5054, and Trichophyton schoenleinii PTCC 5221 were used in this study. For preparing the dermatophytes, they were cultured on Sabauraud dextrose agar and the cultures were incubated at $22.5 \pm 2.5^{\circ} \mathrm{C}$ for 14 days. After growth of dermatophytes, suspensions of dermatophytes were prepared in normal saline with $0.05 \%$ polysorbate- 80 . This suspension was used for further antifungal evaluations.
Anti-dermatophyte activity of $P$. graveolens essential oils by mycelium growth inhibition method

P. graveolens essential oils (200 ppm) were incorporated into Sabauraud dextrose agar. Sabauraud dextrose agar without essential oils was used as controls. Then, the fungal patches were prepared by spreading the dermatophyte suspensions on the surface of Sabauraud dextrose agar and were incubated for 7 days at $25^{\circ} \mathrm{C}$ in aerobic condition. The surface of cultured media $(6 \mathrm{~mm})$ were punched and put on the surface of Sabauraud dextrose agar with or without $P$. graveolens essential oils. The plates were incubated at the same conditions for 7 days. The mycelium growth inhibitions were measured for each plate and the growth inhibition percent were calculated from comparison between the growth in Sabauraud dextrose agar with or without essential oils. The experiment were replicated five times and the means of replicates were used in calculations [22].

\section{Anti-dermatophytes evaluations by micro-broth dilution assay}

For determining the Minimal inhibitory concentration (MIC) and minimal fungicidal concentration (MFC) of $P$. graveolens essential oils, each essential oil were dissolved in dimethyl sulfoxide (DMSO) and serially diluted in RPMI broth media $(8-0.015 \mu \mathrm{l} / \mathrm{ml})$ in 96 micro-titer plates. Then, the adjusted dermatophyte suspensions $\left(10^{3}-10^{4} \mathrm{CFU} / \mathrm{ml}\right)$ in RPMI by spectrophotometric method was added to the wells of plates containing essential oil's serial dilutions, and was incubated at $22.5 \pm$ $2.5^{\circ} \mathrm{C}$ for 5 days. The lowest concentration of essential oil with visible fungal growth inhibition was defined as Minimal Inhibitory Concentration (MIC) and the first dilution with

Table 1 The chemical composition of P. graveolens essential oils

\begin{tabular}{|c|c|c|}
\hline P. graveolens Essential oil & Main components & Source \\
\hline E3 & $\begin{array}{l}\text { Citronellol (29.5\%), linalool (13.4\%), geraniol (10.6\%), citronellyl formate (7.9\%), geranyl } \\
\text { formate }(10.8 \%) \text {, geranyl acetate }(7.2 \%) \text {, limonene }(5 \%)\end{array}$ & Germany \\
\hline E4 & $\begin{array}{l}\text { Citronellol (30.2\%), Geraniol (21.9\%), linalool (11.04\%), citronellyl formate (5\%), geranyl } \\
\text { formate (3.4\%) }\end{array}$ & India \\
\hline E20 & $\begin{array}{l}\text { Geraniol (95.6\%), Trans-caryophyllene }(3.5 \%) \text {, geranyl formate }(1.6 \%) \text {, linalool }(0.7 \%) \text {, } \\
\text { citronellyl formate }(0.3 \%) \text {, citronellol }(0.2 \%)\end{array}$ & India \\
\hline E6 & $\begin{array}{l}\text { Citronellol (41\%), citronellyl formate (12.7\%), geraniol (8\%), geranyl formate }(2.1 \%) \text {, } \\
\text { linalool (1\%) }\end{array}$ & Zanjan, Iran \\
\hline E9 & $\begin{array}{l}\text { Citronellol (48\%), citronellyl formate (16.2\%), geraniol (5.1\%), geranyl formate (3\%), } \\
\text { linalool (1.1\%) }\end{array}$ & Delijan, Markazi Province, Iran \\
\hline E11 & $\begin{array}{l}\text { Citronellol (45.6\%), citronellyl formate (14.1\%), geraniol (3.4\%), geranyl formate (1.6\%), } \\
\text { linalool }(0.8 \%)\end{array}$ & Shahrood, Iran \\
\hline E14 & $\begin{array}{l}\text { Citronellol (34.7\%), geraniol ( } 21.3 \%) \text {, citronellyl formate }(7.4 \%) \text {, linalool (6.3\%), geranyl } \\
\text { formate }(4.4 \%) \text {, geranyl acetate }(1.5 \%)\end{array}$ & $\begin{array}{l}\text { Mashhad-E-Ardehal, Isfahan } \\
\text { Province, Iran }\end{array}$ \\
\hline E21 & $\begin{array}{l}\text { Citronellol (48.3\%), citronellyl formate (10.9\%), geraniol (8.4\%), linalool (2.2\%), geranyl } \\
\text { formate }(1.7 \%)\end{array}$ & Noorabad, Fars Province, Iran \\
\hline E22 & $\begin{array}{l}\text { Citronellol (39.9\%), citronellyl formate (13.4\%), geraniol (4.2\%), geranyl formate (2.8\%), } \\
\text { linalool (1.3\%) }\end{array}$ & Dezfool, Iran \\
\hline
\end{tabular}


no growth after culturing on Sabauraud dextrose Agar was Minimal Fungicidal Concentration (MFC).The experiments were replicated three times [22].

\section{Results and discussion}

Essential oils are favorable natural compounds that can be used as natural alternative treatment for management of dermatophytosis. Citronellol (0.2-48.3\%), geraniol (3.495.6\%), citronellyl formate $(0.3-16.2 \%)$, geranyl formate (1.6-10.8\%), and linalool $(0.7-13.4 \%)$ were the main components of 9 samples of $P$. graveolens essential oils (Table 1). The highest and lowest amounts of geraniol (95.6\%) and citronellol $(0.2 \%)$ were found in $P$. graveolens essential oil $\mathrm{E}_{20}$ from India. Trans-caryophyllene was the second main component of this essential oil (3.5\%), followed by geranyl formate $(1.6 \%)$, and linalool $(0.7 \%)$. The highest amounts of citronellol were in $P$. graveolens essential oil $\mathrm{E}_{21}(48.3 \%), \mathrm{E}_{9}$ (48.0\%), $\mathrm{E}_{11}$ (45.6\%), and $\mathrm{E}_{6}(41 \%)$.

Citronellol was the first main component of 8 samples of $P$. graveolens essential oils, while geraniol was the second main component of 2 samples of $P$. graveolens essential oils $\left(E_{4}\right.$ and $\left.E_{14}\right)$. Linalool was the second main component of one sample $P$. graveolens essential oil. Citronellyl formate was found in 5 samples of $P$. graveolens essential oil as the second main component.

The chemical profiles and main components of $P$. graveolens essential oil were changed from one sample to others. The chemical profile of $P$. graveolens essential oils were not according to standard $P$. graveolens essential oil (BS ISO 4371-2012) [3].

The anti-dermatophyte effects of $P$. graveolens essential oils against dermatophytes by mycelium growth inhibition test exhibited that $P$. graveolens essential oil $E_{20}$ had the highest mycelium growth inhibition percent against dermatophytes (30.9-53.3\%), followed by $\mathrm{E}_{4}$ $(17.8-43.6 \%)$ and $\mathrm{E}_{14}(19.9-43.6 \%)$, respectively. $T$. rubrum had the higher mycelium inhibition percent (22.5-53.3\%) by $P$. graveolens essential oils, followed by M. gypseum (17-45.4\%), and T. mentagrophytes (16.5-
43.6\%). M. canis and T. schoenleinii had the less mycelium inhibition percent by $P$. graveolens essential oils (Table 2).

In micro-broth dilution assay, the MIC and MFC values for $E_{20}$ were in the ranges of 0.03-0.125 and $0.06-0.25 \mu \mathrm{l} / \mathrm{ml}$, respectively. $\mathrm{E}_{14}$ (MIC, MFC values of $0.06-0.125,0.125-0.25 \mu \mathrm{l} / \mathrm{ml}$ ), $\mathrm{E}_{4}$ and $\mathrm{E}_{21}$ (MIC, MFC values of $0.06-0.25, \quad 0.125-0.5 \mu \mathrm{l} / \mathrm{ml})$ showed antidermatophyte activity, followed by $\mathrm{E}_{11}, \mathrm{E}_{9}$ (MIC, MFC values of $0.125-0.25,0.125-0.5 \mu \mathrm{l} / \mathrm{ml}$ ), $\mathrm{E}_{3}$ (MIC, MFC values of $0.125-0.25,0.25-0.5) \mu \mathrm{l} / \mathrm{ml}$ ), $\mathrm{E}_{6}$ (MIC, MFC values of $0.125-0.5,0.25-0.5 \mu \mathrm{l} / \mathrm{ml}) . \mathrm{E}_{22}$ (MIC, MFC values of $0.125-0.5,0.25-1 \mu \mathrm{l} / \mathrm{ml}$ ) had the higher MIC and MFC values against dermatophytes than the others (Table 3).

As the results of anti-dermatophyte screening exhibited that $\mathrm{E}_{20}$ with high amount of geraniol had the highest activity against dermatophytes, followed by $\mathrm{E}_{4}, \mathrm{E}_{14}$. Indeed the $P$. graveolens essential oils with high amount of citronellol and geraniol as the first and second main components had the higher anti-dermatophyte effects. The essential oil with high amounts of citronellol or citronellyl formate showed anti-dermatophytes effects lower than the essential oils with citronellol and geraniol as the main components.

The results of anti-dermatophyte effects of $P$. graveolens essential oils have not been in according to their anti-candidal effects. There was no significant difference in anti-candidal activities of six samples of $P$. graveolens essential oils with citronellol (7.7-43.7\%) and geraniol (19.3-48.5\%) against clinical isolates of C. albicans in regard to inhibition zone diameters and the MIC and MFC values [23].

The results of this study confirmed that corresponding components responsible for anti-dermatophyte activity of $P$. graveolens essential oils were geraniol and citronellol. The mechanism of action for geraniol and citronellol is interfering with cell membrane of dermatophytes and decreasing the ergosterol content of cell by inhibition of ergosterol biosynthesis [24, 25], while the anti-candidal

Table 2 Mycelium growth inhibition of dermatophytes by 200 ppm P. graveolens essential oils

\begin{tabular}{|c|c|c|c|c|c|}
\hline P. graveolens Essential oil & T. schoenleinii & M. gypseum & T. mentagrophytes & T. rubrum & M. canis \\
\hline E21 & 15.9 & 17.0 & 16.5 & 22.5 & 17.2 \\
\hline E6 & 14.5 & 23.1 & 20.4 & 31.8 & 13.9 \\
\hline E22 & 9.8 & 18.7 & 22.6 & 28.5 & 10.3 \\
\hline E14 & 19.9 & 25 & 22.8 & 35.0 & 16.0 \\
\hline E20 & 30.9 & 45.4 & 36.3 & 53.3 & 41.4 \\
\hline E3 & 14.0 & 20.7 & 15.8 & 28.5 & 11.3 \\
\hline E11 & 20.5 & 20.0 & 19.5 & 28.8 & 8.8 \\
\hline E4 & 17.8 & 23.3 & 43.6 & 26.8 & 16.1 \\
\hline E9 & 14.9 & 18.0 & 31.0 & 27.6 & 17.2 \\
\hline
\end{tabular}


Table 3 The antifungal activity of $P$. graveolens essential oils against dermatophytes

\begin{tabular}{|c|c|c|c|c|c|c|c|c|c|c|}
\hline \multirow{2}{*}{$\begin{array}{l}\text { P. graveolens } \\
\text { essential oil }\end{array}$} & \multicolumn{2}{|c|}{ T. schoenleinii } & \multicolumn{2}{|c|}{ M. canis } & \multicolumn{2}{|c|}{ M. gypseum } & \multicolumn{2}{|c|}{ T. mentagrophytes } & \multicolumn{2}{|c|}{ T. rubrum } \\
\hline & MIC & MFC & $\mathrm{MIC}$ & MFC & MIC & MFC & $\mathrm{MIC}$ & MFC & $\mathrm{MIC}$ & MFC \\
\hline E3 & 0.25 & 0.25 & 0.25 & 0.5 & 0.125 & 0.25 & 0.125 & 0.25 & 0.25 & 0.5 \\
\hline E4 & 0.125 & 0.125 & 0.125 & 0.25 & 0.125 & 0.25 & 0.06 & 0.125 & 0.25 & 0.5 \\
\hline E6 & 0.125 & 0.25 & 0.125 & 0.25 & 0.125 & 0.25 & 0.125 & 0.25 & 0.25 & 0.5 \\
\hline E9 & 0.125 & 0.25 & 0.125 & 0.25 & 0.25 & 0.25 & 0.125 & 0.25 & 0.25 & 0.5 \\
\hline E11 & 0.125 & 0.125 & 0.25 & 0.25 & 0.125 & 0.25 & 0.125 & 0.25 & 0.25 & 0.5 \\
\hline E14 & 0.125 & 0.125 & 0.125 & 0.25 & 0.06 & 0.125 & 0.125 & 0.25 & 0.125 & 0.25 \\
\hline E20 & 0.06 & 0.125 & 0.125 & 0.25 & 0.03 & 0.06 & 0.06 & 0.125 & 0.125 & 0.25 \\
\hline E21 & 0.125 & 0.125 & 0.125 & 0.5 & 0.125 & 0.25 & 0.06 & 0.125 & 0.25 & 0.25 \\
\hline E22 & 0.125 & 0.125 & 0.25 & 0.5 & 0.25 & 0.5 & 0.25 & 0.5 & 0.5 & 0.5 \\
\hline Amphotericin & 0.25 & 0.25 & 0.25 & 0.25 & 0.25 & 0.25 & 0.5 & 1 & 0.5 & 0.5 \\
\hline
\end{tabular}

MIC Minimal Inhibitory Concentration $(\mu \mathrm{l} / \mathrm{ml})$, MFC Minimal Fungicidal Concentration $(\mu \mathrm{l} / \mathrm{ml})$

activity against $C$. albicans is not mediated by ergosterol biosynthesis [26].

\section{Conclusions}

Therefore, for preparing anti-dermatophyte products containing $P$. graveolens essential oils, the use of essential oil with main components of geraniol (30-35\%) and citronellol (21\%) are recommended. The third main component of essential oil should be linalool or citronellyl formate in higher percentage of $5 \%$. More studies are required for comparing the efficacy of $P$. graveolens essential oils in animal studies.

\section{Acknowledgements}

This study is approved and performed in Microbiology Department of Medicinal Plant Research center of Barij, Kashan, Iran.

\section{Authors' contributions}

Mehdi Valian prepared and analyzed the essential oils; Mohaddese Mahboubi supervised the study and wrote the manuscript.

\section{Funding}

This study is approved and performed in Microbiology Department of Medicinal Plant Research center of Barij, Kashan, Iran.

\section{Availability of data and materials}

Not applicable.

\section{Ethics approval and consent to participate} Not applicable.

\section{Consent for publication}

The authors declare their consent for publication.

\section{Competing interests}

The authors declare no conflict of Interest.

\section{Author details}

${ }^{1}$ Department of Microbiology, Medicinal Plant, Research Center of Barij, Kashan, Iran. ${ }^{2}$ Department of Phytochemistry, Medicinal Plant, Research Center of Barij, Kashan, Iran.
Received: 29 December 2018 Accepted: 17 July 2019

Published online: 26 July 2019

References

1. Watt JM, Breyer-Brandwijk MG. In: the University of Michigan: Livingstone, editor. The medicinal and poisonous plants of southern and eastern Africa being an account of their medicinal and other uses, chemical composition, pharmacological effects and toxicology in man and animal; 1962.

2. Lis-Balchin M. Geranium and Pelargonium: the genera Geranium and Pelargonium: Taylor \& Francis; 2002

3. BS-ISO-4731. Essential oil of geranium (Pelargonium $\times$ ssp.). 2012.

4. Ćavar S, Maksimović M. Antioxidant activity of essential oil and aqueous extract of Pelargonium graveolens L'Her. Food Control. 2012;23(1):263-7.

5. Ben Slima A, Ali MB, Barkallah M, Traore Al, Boudawara T, Allouche N, et al. Antioxidant properties of Pelargonium graveolens L'Her essential oil on the reproductive damage induced by deltamethrin in mice as compared to alpha-tocopherol. Lipids Health Dis. 2013;12:30.

6. Carmen G, Hancu G. Antimicrobial and antifungal activity of Pelargonium roseum essential oils. Advanced pharmaceutical bulletin. 2014;4(Suppl 2): 511-4.

7. Lis-Balchin M, Buchbauer G, Hirtenlehner T, Resch M. Antimicrobial activity of Pelargonium essential oils added to a quiche filling as a model food system. Lett Appl Microbiol. 1998:27(4):207-10.

8. Andrade MA, Cardoso MG, Batista LR, Freire JM, Nelson DL. Antimicrobial activity and chemical composition of essential oil of Pelargonium odoratissimum. Rev Bras. 2011;21:47-52.

9. Mahboubi M, Kazempour N, Farzin N. Antimicrobial activity of Pelargonium graveolens and Oliveria decumbens extracts against clinical isolates of Staphylococcus aureus. Journal of Biologically Active Products from Nature. 2011;1(2):105-11.

10. Katiyar SK, Mukhtar H. Green tea polyphenol (-)-epigallocatechin-3-gallate treatment to mouse skin prevents UVB-induced infiltration of leukocytes, depletion of antigen-presenting cells. and oxidative stress J Leukoc Biol. 2001:69(5):719-26.

11. Boukhatem MN, Kameli A, Ferhat MA, Saidi F, Mekarnia M. Rose geranium essential oil as a source of new and safe anti-inflammatory drugs. The Libyan journal of medicine. 2013;8:22520.

12. Mahboubi M, Feizabadi MM, Khamechian T, Kazempour N, Razavi Zadeh M, Sasani F, et al. The effect of Oliveria decumbens and Pelargonium graveolens on healing of infected skin wounds in mice. World journal of plastic surgery. 2016;5(3):259-64.

13. Rosato A, Vitali C, Piarulli M, Mazzotta M, Argentieri MP, Mallamaci R. In vitro synergic efficacy of the combination of nystatin with the essential oils of Origanum vulgare and Pelargonium graveolens against some Candida species. Phytomedicine : international journal of phytotherapy and phytopharmacology. 2009;16(10):972-5.

14. Rosato A, Vitali C, Gallo D, Balenzano L, Mallamaci R. The inhibition of Candida species by selected essential oils and their synergism with 
amphotericin B. Phytomedicine : international journal of phytotherapy and phytopharmacology. 2008;15(8):635-8.

15. Shin S, Lim S. Antifungal effects of herbal essential oils alone and in combination with ketoconazole against Trichophyton spp. J Appl Microbiol. 2004;97(6):1289-96.

16. Mahboubi M, Feizabadi M, Safara M. Antifungal activity of essential oils from Zataria multiflora, Rosmarinus officinalis, Lavandula stoechas, Artemisia sieberi Besser and Pelargonium graveolens against clinical isolates of Candida albicans. Pharmacogn Mag. 2008:4:15):15-8.

17. Oke OO, Onayemi O, Olasode OA, Omisore AG, Oninla OA. The prevalence and pattern of superficial fungal infections among school children in lle-lfe, South-Western Nigeria \%J. Dermatology Research and Practice. 2014;2014:7.

18. Kaul S, Yadav S, Dogra S. Treatment of Dermatophytosis in elderly, children, and pregnant women. Indian Dermatol Online J. 2017;8(5):310-8.

19. Ibrahim SY, Abd El-Salam MM. Anti-dermatophyte efficacy and environmental safety of some essential oils commercial and in vitro extracted pure and combined against four keratinophilic pathogenic fungi. Environ Health Prev Med. 2015;20(4):279-86.

20. Mahboubi M. Artemisia sieberi Besser essential oil and treatment of fungal infections. Biomedicine \& pharmacotherapy = Biomedecine \& pharmacotherapie. 2017;89:1422-30.

21. Cavaleiro C, Pinto E, Gonçalves MJ, Salgueiro L. Antifungal activity of Juniperus essential oils against dermatophyte, Aspergillus and Candida strains. J Appl Microbiol. 2006;100(6):1333-8.

22. Mahboubi M, HeidaryTabar R, Mahdizadeh E. The anti-dermatophyte activity of Zataria multiflora essential oils. J Med Mycol. 2017:27(2):232-7.

23. Mahboubi M, Mahdizadeh E, HeidaryTabar R. The anti-candidal activity of Pelargonium graveolens essential oils against clinical isolates of Candida albicans. Infectio. 2018;22:1.

24. Pereira Fde O, Mendes JM, Lima IO, Mota KS, Oliveira WA, Lima Ede O. Antifungal activity of geraniol and citronellol, two monoterpenes alcohols, against Trichophyton rubrum involves inhibition of ergosterol biosynthesis. Pharm Biol. 2015:53(2):228-34.

25. Ismail $\mathrm{H}$. Novel antifungal activity of geraniol and its synergistic effect in combination with fluconazole against resistant Candida albicans. Worcester Polytechnic Institute 2012;Bachelor of Science.

26. Leite MC, de Brito Bezerra AP, de Sousa JP, de Oliveira Lima E. Investigating the antifungal activity and mechanism(s) of geraniol against Candida albicans strains. Med Mycol. 2015;53(3):275-84.

\section{Publisher's Note}

Springer Nature remains neutral with regard to jurisdictional claims in published maps and institutional affiliations.

\section{Submit your manuscript to a SpringerOpen ${ }^{\circ}$ journal and benefit from:}

- Convenient online submission

- Rigorous peer review

- Open access: articles freely available online

- High visibility within the field

- Retaining the copyright to your article

Submit your next manuscript at $\boldsymbol{\nabla}$ springeropen.com 